\title{
Poética da penumbra, poética da escuridão
}

Poetics of Penumbra, Poetics of Darkness 


\section{Resumo}

Com base nas leituras de poemas do chileno Nicanor Parra (1914-2018) e do argentino Jorge Luis Borges (1899-1989), este estudo investiga a construção do que chamei de uma poética da penumbra ou poética da escuridão. $\mathrm{O}$ objetivo foi investigar as manifestações da imagem da sombra, da falta de luz ou de visão como possibilidade de outras experiências tanto no campo da arte quanto do saber. No caminho oposto ao de uma perspectiva iluminista, fundada na ideia de esclarecimento, evolução e progresso, a poética da penumbra e a poética da escuridão (gradações de um mesmo espectro criativo) conduzem a uma tomada de consciência histórica por parte do indivíduo, levado a compreender sua situação histórica por meio de uma abordagem dialética e não linear de suas próprias práticas, comportamentos e reflexões.

Palavras-chave: Poesia; Nicanor Parra; Jorge Luis Borges

\section{Resumen}

Basándose en las lecturas de poemas del chileno Nicanor Parra (1914-2018) y del argentino Jorge Luis Borges (1899-1989), este estudio investiga la construcción de lo que llamé una poética de la penumbra o poética de la oscuridad. El objetivo fue investigar las manifestaciones de la imagen de la sombra, la falta de luz o de visión como posibilidad de experiencias otras en el campo del arte y del conocimiento. En un camino distinto al de una perspectiva de la Ilustración, fundada en la idea de la iluminación, la evolución y el progreso, la poética de la penumbra y la poética de la oscuridad (gradaciones del mismo espectro creativo) conducen a que el individuo tome conciencia de la historia, lo que lleva a la comprensión de su situación histórica a través de un enfoque dialéctico y no lineal de sus propias prácticas, comportamientos y reflexiones.

Palabras clave: Poesía; Nicanor Parra; Jorge Luis Borges 


\title{
Poética da penumbra
}

Em "Catalina Parra", poema escrito em 1944 e publicado em Poemasy antipoemas (1954), o poeta chileno Nicanor Parra ensaia o que chamo de uma poética da penumbra. O título do poema - um nome próprio - direciona a leitura para a relevância e para a determinação de um outro específico. O poema foi escrito nos Estados Unidos, quando Parra estudava na Brown University, longe de sua filha, então recém-nascida ${ }^{1}$. Essa relação à distância será desenvolvida ao longo de oito quartetos compostos por versos hexassílabos e rimas assonantes. Segundo o crítico René Costa, em "Catalina Parra", Nicanor "[...] muy bábilmente utiliza la rima como una especie de falsilla para ordenar el poema, baciendo resonar el nombre de la bija ausente del poeta, nombre que a su vez. da la medida hexasilábica del verso"':

\author{
Caminando solo \\ Por ciudad extraña \\ Qué será de nuestra \\ Catalina Parra. \\ Cuánto tiempo ¡un año! \\ Que no sé palabra \\ De esta memorable \\ Catalina Parra. \\ Bajo impenitente, \\ Lluvia derramada \\ Dónde irá la pobre \\ Catalina Parra. \\ ¡Ah, si yo supiera! \\ Pero no sé nada \\ Cuál es tu destino \\ Catalina Pálida. \\ Sólo sé que mientras \\ Digo estas palabras
}

1 No seu livro Poesia e escolhas afetivas, Luciana di Leone aponta a intensa presença dos nomes próprios como evidência da "presença do outro" na escrita de poesia. "Esse fato solicita não uma leitura que procure debelar os eventos biográficos compartilhados e referidos - como se o 'real' ou a 'vida' fossem o sentido último e verdadeiro do texto -, mas uma leitura que seja capaz de ver as marcas das aberturas do texto ao seu fora, dado que se apresenta afetado por diversas forças, textuais ou não, apagando no final das contas essa fronteira." Di Leone defende com muita propriedade que esses nomes apontam para uma "característica relacional ou transitiva e afetiva da poesia". Cf. DI LEONE, Luciana. Poesia e escolhas afetivas, 2014, p. 171-177.

2 "[...] muito habilmente utiliza a rima como uma espécie de falseio para organizar o poema, fazendo ressoar o nome da filha ausente [...], nome que por sua vez dá a medida hexassilábica do verso”. DE COSTA, René. "Para una poética de la (anti)poesía", 2017, p. 28. 


$$
\begin{aligned}
& \text { En volver a verte } \\
& \text { Cifro la esperanza. } \\
& \text { Aunque sólo seas } \\
& \text { Vista a la distancia } \\
& \text { Niña inolvidable, } \\
& \text { Catalina Parra. } \\
& \text { Hija mía, „cuántas } \\
& \text { Veces comparada } \\
& \text { Con la rutilante } \\
& \text { Luz de la mañana! } \\
& \text { Ay, amor perdido, } \\
& \text { ¿Lámpara sellada! } \\
& \text { Que esta rosa nunca } \\
& \text { Pierda su fragancia }{ }^{3} \text {. }
\end{aligned}
$$

O nome de Catalina Parra, a filha ausente de Nicanor, ecoa em sua própria ausência. Os sinais de exclamação pontuam momentos de tensão, expressam graficamente um estado de espírito exaltado, expressam o assombro diante do tempo [“Cuánto tiempo jun año?’], do desconhecido [“" Ah, si yo supiera?’], da natureza [“Luz de la mañana?’] e da escuridão [“'Lámpara sellada!’]. Sensações de isolamento, solidão e dúvida envolvem o sujeito; a elas vem somar-se um ar nostálgico que impele o indivíduo a confrontar-se com o espaço estranho em que se encontra. Quase sempre esse espaço, ou mais precisamente a sensação de ser um estrangeiro num lugar estranho, impele o indivíduo à errância. "Caminando solo/Por ciudad extraña", Nicanor Parra desenha a imagem do poeta romântico, condensando em apenas dois versos o que os teóricos do romantismo alemão elaboraram ao longo de décadas em inúmeros tratados, ensaios, cartas, dramas e poemas. Em certa altura, a nostalgia, a distância e o desterro tornam-se um "sentido da arte e do mundo" para os românticos. "Por esto hablan tanto del caminar, del caminar sin meta ni fin"

A “nostalgia da pátria” era a principal energia do "desterro" romântico. Mas, a distância não é apenas a medida da separação entre dois pontos no tempo e no espaço, tampouco é apenas uma consequência do isolamento. Em seus trabalhos, Edgar Allan

3 “Caminhando só/Por cidade estranha/Que será de nossa/Catalina Parra.//Quanto tempo um ano!/ Que não sei palavra/Desta memorável/Catalina Parra.//Sob impenitente/Chuva derramada/Onde irá a pobre/Catalina Parra.//Ah, se eu soubesse!/Mas eu não sei nada/Qual é teu destino/Catalina Pálida.//Só sei que enquanto/Digo estas palavras/De voltar a ver-te/Cifro a esperança.//Ainda que só sejas/Vista à distância,/Minha inesquecível,/Catalina Parra.//Filha minha, quantas/Vezes comparada/ Com a rutilante/Luz da alvorada!//Ai, amor perdido,/Lâmpada selada!/Que esta rosa nunca/Perca sua fragrância." PARRA, Nicanor. "Catalina Parra”, 1969, p. 17-18.

4 "Por isso falam tanto do caminhar, do caminhar sem meta nem fim". HAUSER, Arnold. Historia social de la literatura y del arte, v. 2, 1976, p. 352. 
Poe e Charles Baudelaire descreveram assiduamente a solidão do indivíduo moderno, mesmo quando confrontado com as multidões metropolitanas ${ }^{5}$.

Nada mais terrível do que experimentar essa distância de si mesmo no preciso momento em que o desconhecido é materializado em corpos que passam, fluem e desaparecem; olhares cruzam-se como rápidos relâmpagos; vidas inteiras são reduzidas a um átimo, submetidas à velocidade dos transportes coletivos que cruzam as ruas. Além disso, os poetas românticos sabiam que a distância era também o desconhecido, a opacidade do "real" e uma carência eterna que nem a maior das paixões poderia suprir, e que, no entanto, é a fonte inesgotável de todas as paixões. Nenhuma distância pode ser maior do que aquela que separava Édipo do assassino de Laio.

";Ah, si yo supiera!/Pero no sé nada”, escreve Nicanor. E é precisamente diante dessa constatação e de uma suprema dúvida em relação ao destino que o nome da filha do poeta se deforma, empalidece, oscila e desaparece do poema. A oscilação do nome, suprimido numa estrofe e recolocado na seguinte, cria "[...] un espacio para el eco. El eco de la ausencia, haciendo que se lea la última estrofa presintiendo ese nombre ausente precisamente donde más falta, como ella misma [Catalina Parra], al final del poema".

Além de estar presente em "Catalina Parra", a imagem da lâmpada aparece em outros três poemas da primeira seção de Poemas y antipoemas: "Hay un día feliz", "Es olvido" e "Se canta al mar". Os três aparecem em sequência. Em "Hay un día feliz", o sujeito poético narra uma visita à aldeia de sua infância durante uma tarde de outono. O outono é o mesmo da sua infância e permanece com sua "difusa lámpara de niebla". O poeta vadia pela aldeia, num caminhar solitário; vê andorinhas no topo da torre de uma igreja. O tom imprime no poema um sentimento emocionado, provocado por uma ligação integral entre o sujeito e o espaço percorrido:

\footnotetext{
A recorrer me dediqué esta tarde

Las solitarias calles de mi aldea

Acompañado por el buen crepúsculo

Que es el único amigo que me queda.

Todo está como entonces, el otoño

Y su difusa lámpara de niebla,

Sólo que el tiempo lo ha invadido todo

Con su pálido manto de tristeza.

Nunca pensé, creédmelo, un instante

Volver a ver esta querida tierra,

Pero ahora que he vuelto no comprendo
}

5 Cf. Benjamin, Walter. A modernidade e os modernos, 2000.

6 "[...] um espaço para o eco. O eco da ausência, fazendo com que se leia a última estrofe pressentindo esse nome ausente precisamente onde ele mais falta, como ela mesma [Catalina], ao fim do poema". DE COSTA, René. "Para una poética de la (anti)poesía", 2017, p. 29. 
Cómo pude alejarme de su puerta.

Nada ha cambiado, ni sus casas blancas

$\mathrm{Ni}$ sus viejos portones de madera.

Todo está en su lugar; las golondrinas

En la torre más alta de la iglesia;

El caracol en el jardín, y el musgo

En las húmedas manos de las piedras.

No se puede dudar, éste es el reino

Del cielo azul y de las hojas secas

En donde todo y cada cosa tiene

Su singular y plácida leyenda:

Hasta en la propia sombra reconozco

La mirada celeste de mi abuela.

Estos fueron los hechos memorables

Que presenció mi juventud primera,

El correo en la esquina de la plaza

Y la humedad en las murallas viejas.

¡Buena cosa, Dios mío! nunca sabe

Uno apreciar la dicha verdadera,

Cuando la imaginamos más lejana

Es justamente cuando está más cerca.

Ay de mí, jay de mí!, algo me dice

Que la vida no es más que una quimera;

Una ilusión, un sueño sin orillas,

Una pequeña nube pasajera.

Vamos por partes, no sé bien qué digo,

La emoción se me sube a la cabeza.

Como ya era la hora del silencio

Cuando emprendí mi singular empresa,

Una tras otra, en oleaje mudo,

$\mathrm{Al}$ establo volvían las ovejas.

Las saludé personalmente a todas

Y cuando estuve frente a la arboleda

Que alimenta el oído del viajero

Con su inefable música secreta

Recordé el mar y enumeré las hojas

En homenaje a mis hermanas muertas.

Perfectamente bien. Seguí mi viaje

Como quien de la vida nada espera.

Pasé frente a la rueda del molino,

Me detuve delante de una tienda:

El olor del café siempre es el mismo,

Siempre la misma luna en mi cabeza;

Entre el río de entonces y el de ahora

No distingo ninguna diferencia.

Lo reconozco bien, éste es el árbol

Que mi padre plantó frente a la puerta

(Ilustre padre que en sus buenos tiempos

Fuera mejor que una ventana abierta).

Yo me atrevo a afirmar que su conducta

Era un trasunto fiel de la Edad Media

Cuando el perro dormía dulcemente

Bajo el ángulo recto de una estrella.

A estas alturas siento que me envuelve

El delicado olor de las violetas

Que mi amorosa madre cultivaba

Para curar la tos y la tristeza. 
Cuánto tiempo ha pasado desde entonces

No podría decirlo con certeza;

Todo está igual, seguramente,

El vino y el ruiseñor encima de la mesa,

Mis hermanos menores a esta hora

Deben venir de vuelta de la escuela:

¡Sólo que el tiempo lo ha borrado todo

Como una blanca tempestad de arena!

Em certa altura do poema, o sujeito poético perde-se em elucubrações inflamadas e é tomado por uma súbita felicidade, uma espécie de revelação da "verdade": "¡Buena cosa, Dios mío! nunca sabe/Uno apreciar la dicha verdadera,/Cuando la imaginamos más lejana/Es justamente cuando está más cerca." Essa espécie de iluminação é provocada pelo retorno ao lar: o lugar onde o poeta viveu a sua "juventud primera". Verso a verso, Nicanor Parra compõe um ambiente rural, pastoril, onde o perfume de violetas, os arvoredos e os rouxinóis estimulam o olfato, a visão e a audição. O poeta chega a casa. É a hora em que os seus irmãos menores devem estar voltando da escola. Tudo está igual. Tudo como antes: "Sólo que el tiempo lo ha borrado todo/Como una blanca

7 "Me dediquei a percorrer esta tarde/As ruas solitárias de minha aldeia/Acompanhado pelo bom crepúsculo/Que é o único amigo que me resta./Tudo está como era antes, o outono/E sua difusa lâmpada de névoa,/Só que o tempo invadiu a tudo/Com seu pálido manto de tristeza./Nunca pensei, acreditem, um instante/Voltar a ver esta querida terra,/Mas agora que voltei não compreendo/Como pude afastar-me de sua porta./Nada mudou, nem suas casas brancas/Nem seus velhos portões de madeira./Tudo está em seu lugar; as andorinhas/ $\mathrm{Na}$ torre mais alta da igreja;/O caracol no jardim, e o musgo/Nas úmidas mãos das pedras./Não se pode duvidar, este é o reino/Do céu azul e das folhas secas/Onde tudo e cada coisa tem/A sua singular e plácida legenda:/Até na minha própria sombra reconheço/De minha avó o olhar celeste./Estes foram os fatos memoráveis/Que testemunhou minha juventude primeira,/O correio na esquina da praça/E a umidade nas paredes velhas./Boa coisa, meu Deus! Nunca sabemos/ Apreciar a felicidade verdadeira,/Quando a imaginamos mais distante/É justamente quando está mais perto./Ai de mim, ai de mim!, algo me diz/Que a vida não é mais que uma quimera;/Uma ilusão, um sonho sem fronteiras,/Uma pequena nuvem passageira./Vamos por partes, não sei bem o que digo,/A emoção me sobe à cabeça./Como era hora do silêncio/Quando empreendi minha singular proeza,/ Uma após a outra, em ondas mudas,/Voltavam ao estábulo as ovelhas./Cumprimentei pessoalmente todas elas/E quando estive frente ao arvoredo/Que alimenta o ouvido do viajante/Com a sua inefável música secreta/Lembrei-me do mar e enumerei as folhas/Em homenagem às minhas irmãs mortas./ Perfeitamente bem. Segui minha viagem/Como quem da vida nada espera./Passei em frente à roda do moinho,/Me detive diante de uma venda:/O cheiro do café sempre é o mesmo,/Sempre a mesma lua em minha cabeça;/Entre o rio de então e o de agora/Não distingo nenhuma diferença./Eu reconheço bem, esta é a árvore/Que meu pai plantou em frente à porta/(ilustre pai que em seus bons tempos/Foi melhor que uma janela aberta)./Atrevo-me a dizer que sua conduta/Era uma transcrição fiel da Idade Média/Quando o cachorro dormia docemente/Sob o ângulo reto de uma estrela./A essa altura sinto que me envolve/O delicado odor das violetas/Que minha amorosa mãe cultivava/Para curar a tosse e a tristeza./Quanto tempo passou desde então/Não poderia dizê-lo ao certo;/Tudo está igual, seguramente,/O vinho e o rouxinol em cima da mesa,/Os meus irmãos mais novos a esta hora/Devem vir de volta da escola:/Só que o tempo apagou a tudo/Como uma branca tempestade de areia!" PARRA, Nicanor. Obra gruesa,1969, p. 20-22. 
tempestad de arena?' O retorno não era mais do que uma lembrança cristalizada, uma fotografia desbotada. A distância temporal entre o poeta e a aldeia da sua infância foi apagada pelo tempo e pelo tempo pode ser resgatada, momentaneamente, mediante o retorno ao passado empreendido sistematicamente a partir do romantismo.

A "difusa lámpara de niebla" e a "lámpara sellada" são imagens dúbias. Elas apresentam um instrumento de iluminação, uma metáfora do pensamento, da inteligência e da criação, ${ }^{8}$ mas acrescentam a esse instrumento e a essa metáfora um modificador negativo. Surge daí a tensão dialética entre a necessidade do isolamento e da escuridão e a perturbação provocada pela satisfação dessas necessidades. Os poetas do romantismo alemão foram os primeiros a incorporar essa dialética em seus poemas. Já que ela não podia resolver-se, eles a abraçaram.

Em "Es olvido" e "Se canta al mar", repete-se o movimento retorno ao passado. No primeiro, o poeta lembra de uma jovem que o amou sem que ele soubesse. "Ella que era una lámpara legítima", ${ }^{9}$ ele diz, porém, ela está morta, apagada. A mínima iluminação da memória não é forte o bastante para conter essa treva, e o poeta a esqueceu, sem querer, lentamente, como todas as coisas da vida. Aqui, o tempo e o esquecimento se confundem. No segundo, Nicanor Parra conta o episódio em que é levado pelo pai para ver o mar pela primeira vez. O episódio é narrado como um instante de arrebatamento frente à grandiosidade da natureza. Sobre esse instante de iluminação, Parra escreveu de modo romântico e categórico: "Nada podrá apartar de mi memoria/La luz de aquella misteriosa lámpara". ${ }^{10}$ É curioso que, mesmo aqui, num instante de extrema intensidade, a imagem da lâmpada preserve a sua aura oblíqua de mistério e encantamento, uma aura mórbida, lânguida, como a luz bruxuleante de uma vela, uma "luz, mortecina".

8 Segundo Meyer Abrams, o espelho e a lâmpada são "[...] two commons and antithetic metaphors of mind, one comparing to a reflector of external objects, the other to a radiant projector which makes a contribution to the objects its perceives. The first was characteristic of much of the thinking from Plato to the eighteenth century; the second typifies the prevailing romantic conception of the poetic mind [duas metáforas comuns e antitéticas para definir o intelecto, uma comparando-o a um refletor de objetos externos, a outra comparando-o a um radiante projetor que contribui para a sua percepção dos objetos. A primeira dessas metáforas era característica de boa parte do pensamento desde Platão até o século XVIII; a segunda tipifica a concepção romântica predominante em relação à inteligência poética]". ABRAMS, Meyer H. "Preface", 1971, n.p.

9 PARRA, Nicanor. Obra gruesa, 1969, p. 24.

10 Ibidem, p. 25. 


\section{Poética da escuridão}

Num dos poemas em que experimenta uma assimilação poética da sua própria cegueira, Borges constata, com uma placidez assombrosa, que diante da irreversibilidade da sua condição, já não resta outra alternativa senão fazer um "Elogio de la sombra", célebre poema de 1969.

La vejez (tal es el nombre que los otros le dan) puede ser el tiempo de nuestra dicha.

El animal ha muerto o casi ha muerto.

Quedan el hombre y su alma.

Vivo entre formas luminosas y vagas

que no son aún la tiniebla.

Buenos Aires,

que antes se desgarraba en arrabales

hacia la llanura incesante,

ha vuelto a ser la Recoleta, el Retiro,

las borrosas calles del Once

y las precarias casas viejas

que aún llamamos el Sur.

Siempre en mi vida fueron demasiadas las cosas;

Demócrito de Abdera se arrancó los ojos para pensar;

el tiempo ha sido mi Demócrito.

Esta penumbra es lenta y no duele;

fluye por un manso declive

y se parece a la eternidad.

Mis amigos no tienen cara,

las mujeres son lo que fueron hace ya tantos años,

las esquinas pueden ser otras,

no hay letras en las páginas de los libros.

Todo esto debería atemorizarme,

pero es una dulzura, un regreso.

De las generaciones de los textos que hay en la tierra

sólo habré leído unos pocos,

los que sigo leyendo en la memoria,

leyendo y transformando.

Del Sur, del Este, del Oeste, del Norte,

convergen los caminos que me han traído

a mi secreto centro.

Esos caminos fueron ecos y pasos,

mujeres, hombres, agonías, resurrecciones,

días y noches,

entresueños y sueños,

cada ínfimo instante del ayer

y de los ayeres del mundo, 


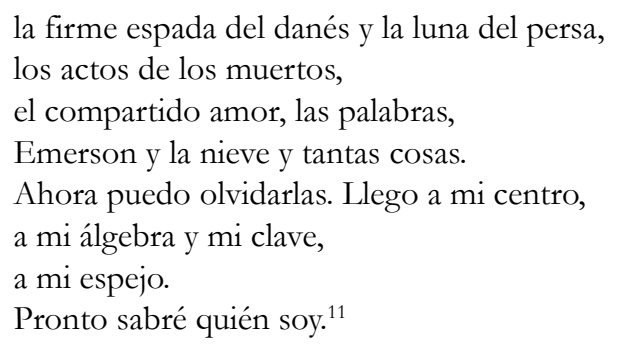

Imerso em um mundo tomado pela escuridão, pelo apagamento dos rostos dos amigos e das páginas dos livros, Borges encontra refúgio na memória. Destino fatal: as sombras eliminam uma dimensão temporal atualizada pelo sentido da visão; se é pela visão que conhecemos, dia após dia, a passagem do tempo na figura dos objetos e a expansão do universo nas imagens que antes não havia, Borges conclui: "La vejez (tal es el nombre que los otros le dan)/puede ser el tiempo de nuestra dicha"12. Conclui, também, que é possível renomear uma experiência à medida que ela se dá e em virtude de como acontece. A experiência vivida pelo indivíduo, considerada por Walter Benjamin o paradigma da experiência moderna, apesar de precária - como a experiência coletiva - apesar de "pobre", tem a capacidade de renomear". "Ela o impele a partir para a frente", segundo Benjamin, "a começar de novo, a contentar-se com pouco, a construir com pouco, sem olhar nem para a direita nem para a esquerda" ${ }^{14}$. Ainda que na escuridão, ela pode recomeçar, a partir do zero.

"Vivo entre formas luminosas y vagas/ que no son aún la tiniebla", ${ }^{15}$ escreve Borges, invertendo o mito platônico do avanço positivo e gradual em direção ao conhecimento da ideia do bem, percebida no limite do cognoscível e não sem o devido esforço.

$\mathrm{Na}$ conhecida imagem do livro VII d'A república, a passagem da escuridão do interior da caverna para a claridade do seu exterior é marcada pela violência. Acostumado à escuridão, o indivíduo retirado da caverna precisaria adaptar-se à luz se quisesse ver os objetos da região superior. Trata-se de um lento, difícil e recompensador aprendizado; trata-se do abandono gradual da ignorância por meio da instrução: a "iluminação" do indivíduo. A arte do parto socrática [maieutike], apesar da dor e do esforço, dá à luz a ideia. Mas há, nessa mesma narrativa [mithós], uma passagem um tanto esquecida pelos comentadores; nela, Sócrates reflete sobre a possibilidade do

11 BORGES, Jorge Luis. Elogio de la sombra, 1969, p. 155-156.

12 “A velhice (tal é o nome que os outros lhe dão)/pode ser o tempo de nossa felicidade." Ibidem, p. 155.

13 Cf. GAGNEBIN, Jeanne-Marie. "Prefácio - Walter Benjamin ou a história aberta”, 1987, p. 7-19.

14 BENJAMIN, Walter. Obras escolhidas, vol. 1, 1987, p. 116.

15 "Vivo entre formas luminosas e vagas/que ainda não são a treva." BORGES, Jorge Luis, Elogio de la sombra, 1969, p. 155. 
caminho inverso: o indivíduo esclarecido retorna à caverna, seus olhos são fustigados pelas trevas, sua vista se confunde, ele precisa readaptar-se à escuridão ${ }^{16}$.

O retorno à escuridão, que no poema de Borges também significa uma construção subjetiva do tempo e do conhecimento, obriga o poeta a lançar-se num embate com o passado para apreender na escuridão do presente a sua relação com o seu próprio tempo, com a sua contemporaneidade, “[...] uma singular relação com o próprio tempo, que adere a este e, ao mesmo tempo, dele toma distâncias [...]", nas palavras de Giorgio Agamben ${ }^{17}$. Essa relação de anacronismo, no entanto, exige que o sujeito mantenha o olhar fixo no seu tempo, ainda que deslocado para outro, como Borges ao relançar as figuras da memória sobre a sua atual condição, ao revivê-las, ao retornar para elas e, ao mesmo tempo, a partir delas, para o futuro; tudo isso não traz nenhum aspecto de fuga nostálgica ou ilusória, mas tão somente o reflexo de um assumido compromisso com seu tempo por parte do poeta contemporâneo, “[...] aquele que mantém fixo o olhar no seu tempo, para nele perceber não as luzes, mas o escuro" $"$.

Borges conheceu muito bem esse retorno ao escuro, experienciando-o literalmente, reaprendendo a avaliar a percepção do seu próprio tempo e do seu próprio pensamento. Ao contrário da saída do indivíduo da caverna na alegoria de Platão, Borges conta-nos que a chegada da penumbra, para ele, "es lenta y no duele”. Mas não se trata de uma resignação pura. A sabedoria popular está certa em dizer que uma porta se abre quando outra se fecha. As condições em que isto se dá podem ser as piores, é verdade. Não faz bem pôr de lado a desconfiança e o medo. A ação do tempo é involuntária ${ }^{19}$. Borges não arrancou os próprios olhos para pensar, como teria feito Demócrito de Abdera. A velhice roubou-lhe a visão, mas deu-lhe o pensamento. Uma troca justa, para Borges, que encena em seu "Elogio de la sombra" a aceitação estoica do $\operatorname{acaso}^{20}$.

16 Cf. PLATÃO. A república, 2014, p. 315-321.

17 AGAMBEN, Giorgio. O que é o contemporâneo? e outros ensaios, 2009, p. 59.

18 Ibidem, p. 62.

19 "Nadie rebaje a lágrima o reproche/ esta declaración de la maestría/ de Dios, que con magnífica ironíal me dio a la vez los libros y la noche [Ninguém rebaixe a lágrima ou reprove/esta declaração da maestria/de Deus, que com magnífica ironia/me deu de uma só vez os livros e a noite].” BORGES, Jorge Luis. Obras completas (1923-1972), 1984, p. 809.

20 Em 1955, Borges foi nomeado diretor da Biblioteca Nacional da República Argentina. A essa altura, sua visão debilitada pelo aprofundamento da cegueira tornaria o cargo uma ironia do destino: "Poco a poco fui comprendiendo la extraña ironía de los hechos. Yo siempre me habia imaginado el Paraíso bajo la especie de una biblioteca. Ahi estaba yo. Era, de algún modo, el centro de novecientos mil volúmenes en diversos idiomas. Comprobé que apenas podía descifrar las carátulas y los lomos. Entonces escribi el Poema de los dones [Pouco a pouco fui compreendendo a estranha ironia dos fatos. Eu sempre tinha imaginado o Paraíso como uma espécie de biblioteca. Aí estava eu. Era, de algum modo, o centro de novecentos mil volumes em diversos idiomas. 
"Esta penumbra es lenta y no duele;/ fluye por un manso declive/y se parece a la eternidad"21. É com essa imagem plácida e suave que Borges descreve o inevitável avanço da treva. Enquanto isso, o mundo conhecido se desmancha e desaparece. Amigos, lugares, objetos deixam de existir ou são modificados pelo escurecimento. "Todo esto debería atemorizarme", Borges escreve, "pero es una dulzura, un regreso" 22 . Essa ideia de regresso presente no poema de Borges conjuga o tempo, a memória e, sobretudo, o redescobrimento de si. Borges precisou reaprender a enxergar o escuro, a readaptarse às sombras, como o indivíduo que retorna à caverna. Implacável consequência do tempo, o retorno de Borges à cegueira é um retorno ao futuro, a um corpo diferente, estranho, incapaz de enxergar. É um regresso a uma experiência nunca vivida, a um ponto de partida, e não a um apocalíptico destino final.

Em "Palabras a Tomás Lago", poema publicado pelo chileno Nicanor Parra em 1954, portanto quinze anos antes de "Elogio de la sombra", há uma noção semelhante de regresso ao desconhecido. Não se trata aqui, como em Borges, de um monólogo, mas de um diálogo com um amigo, um companheiro de estrada. Destaque-se, o título do poema é uma dedicatória.

\author{
Antes de entrar en materia, \\ Antes, pero mucho antes de entrar en espíritu, \\ Piensa un poco en ti mismo, Tomás \\ Lago y considera lo que está por venir, \\ También lo que está por huir para siempre \\ De ti, de mí, \\ De las personas que nos escuchan. \\ Me refiero a una sombra, \\ $[\ldots]$
}

Como atingir essa anterioridade? Como voltar para esse "antes" da matéria, para esse "antes" do espírito? Como pensar antes da matéria e antes do espírito? Como pensar antes da existência? Não parece haver outra resposta senão o regresso à caverna: o lento retorno a um estágio anterior ao conhecimento das luzes; um retorno, sobretudo, ao próprio sujeito, às pequenas coisas que o cercam, às suas lembranças e aflições cotidianas, bem como aos sonhos e êxtases intermitentes de uma vida atravessada pelo tédio. "Piensa un poco en ti mismo, Tomás", escreve Nicanor Parra. Pode

Comprovei que podia decifrar apenas as capas e as lombadas. Então escrevi o Poema das dádivas]". Idem. Siete noches (Conferencias pronunciadas por Borges en 1977), 1980, p. 144-160.

21 "Essa penumbra é lenta e não dói;/ flui por um manso declive/e se parece com a eternidade." Idem. Elogio de la sombra, 1969, p. 155.

22 “Tudo isso deveria amedrontar-me/mas é uma doçura, um regresso." Ibidem. 
ser que nesse momento a poesia torne-se um simples conselho de amigo e o poema não se diferencie - a não ser pelo corte dos versos - das cartas que Nicanor escreveu a Tomás. Nesse verso sui generis, um enjambement atravessa um nome próprio: "Piensa un poco en ti mismo, Tomás/Lago"... É como se a poesia quisesse intervir nessas palavras circunstanciais, afirmando a condição do poema unicamente por meio da técnica.

É verdade que amigos chamam-se pelo primeiro nome. Nicanor e Tomás compartilhavam uma intimidade que se torna pública na práxis poética. Afeição e cuidado apresentam-se neste verso: "Piensa un poco en ti mismo, Tomás"; porém, logo em seguida, o enjambement formaliza o que até então era banal; acrescenta o sobrenome "Lago" e estabelece uma mínima distância, uma cisão, entre o amigo e a personalidade do homem de letras, poeta e incansável ativista em favor da cultura chilena ${ }^{23}$.

São experiências que povoam "Elogio de la sombra", de Jorge Luis Borges: a experiência da cegueira, a ação do tempo sobre Borges, seu lento e indolor regresso à escuridão. São experiências que povoam "Palabras a Tomás Lago", de Nicanor Parra: a experiência de uma amizade. Esses poemas não lidam com teorias. Os princípios estéticos são a última coisa com a qual eles se preocupam. No prólogo da terceira edição de Elogio de la sombra, Borges escreve: "No soy poseedor de una estética. El tiempo me ha enseñado algunas astucias: eludir los sinónimos [...]; eludir hispanismos, argentinismos, arcaismos y neologismos; preferir las palabras habituales a las palabras asombrosas; intercalar en un relato rasgos circunstanciales, exigidos abora por el lector."24 "Astucias", bluffs.

O que o tempo ensinou a Borges sobrepõe-se a uma teoria estética. As

23 Homero utilizava o que os franceses chamam "enjambement avec rejet" para reiterar uma palavra ou explorar um determinado campo semântico na elaboração de uma cena. Conforme uma preciosa observação de Christian Werner, vemos que na Odisseia “[...] colaboram para o ritmo e a construção de sentido do poema tanto os enjambements quanto a posição em que determinado termo ou fórmula [...] se encontra no verso." Em "Palabras a Tomás Lago", o sobrenome "Lago" é o elemento rejeitado e lançado para baixo. Se a operação do corte enfatiza esse elemento, enfatiza também a sua queda, num movimento duplo, percebido apenas na práxis da poesia feita para os olhos. A leitura de um poema permite-me a criação de um espaço gráfico na página, o estabelecimento de coordenadas espaciais mais ou menos precisas. Na poesia oral e nas canções, o enjambement pode ocultar-se em seu efeito; na escrita, o procedimento é revelado, exposto aos meus olhos. Quando leio um enjambement, reconheço que o verso mergulha de cabeça "no abismo do sentido", transgredindo a sua identidade. Em "Palabras a Tomás Lago", o sobrenome "Lago" é o elemento rejeitado e lançado para baixo. Se a operação do corte enfatiza esse elemento, enfatiza também a sua queda, num movimento duplo, percebido apenas na práxis da poesia feita para os olhos. A leitura de um poema permite-me a criação de um espaço gráfico na página, o estabelecimento de coordenadas espaciais mais ou menos precisas. Na poesia oral e nas canções, o enjambement pode ocultar-se em seu efeito; na escrita, o procedimento é revelado, exposto aos meus olhos. Quando leio um enjambement, reconheço que o verso mergulha de cabeça "no abismo do sentido", transgredindo a sua identidade. Cf. WERNER, Christian. "Introdução”, 2014, n.p. AGAMBEN, Giorgio. Ideia da prosa, 1999, p. 32.

24 "Não possuo uma estética. O tempo me ensinou algumas astúcias: elidir os sinônimos [...]; elidir hispanismos, argentinismos, arcaísmos e neologismos; preferir as palavras habituais às palavras assom- 
"palabras habituales" e os "rasgos circunstanciales" são incorporados em sua poesia. Não sem razão, faz parte de Elogio de la sombra o poema "Heráclito", no qual pode-se ler que o tempo possui dois hábitos: a manhã e a noite. "El segundo crepúsculo./Ese otro hábito del tiempo, la noche. / La purificación y el olvido"25 são expressões apreciadas por Jorge Luis Borges. A transformação do mundo e as experiências passam pela captura da memória, "esa moneda que no es nunca la misma" ("Juan", I, 14); ${ }^{26}$ elemento de valor, mas incapaz de estabilizar os fatos ou mantê-los na esfera do imutável. A purificação e o esquecimento complementam-se; esquecer, desaprender, retornar ao escuro da caverna são gestos tão importantes quanto a recordação. Em "Heráclito", Borges escreve: "Acaso de mi sombra/surgen, fatales e ilusorios, los dias" 27 . Aparentemente, para ele, a escuridão e a sombra apresentam uma possibilidade de ruptura e renascimento. Em "Palabras a Tomás Lago", de Nicanor Parra, a noção de regresso a um estado anterior à matéria e anterior ao espírito traz o aspecto sombrio do ato de despir-se dos preceitos adquiridos em favor de uma reestruturação do conhecimento de si e do outro. Tal noção de regresso, assim como no poema de Borges, é um reencontro com um tempo no qual ele jamais esteve, ainda que este tempo não esteja consolidado, ainda que seja um artefato imaginário, fatal ou ilusório. É nesse sentido que, em "Palabras a Tomás Lago", Nicanor Parra aconselha a Tomás um movimento de retorno para antes da matéria e do espírito, aconselha-o a pensar um pouco em si mesmo, mas não deixa de advertir que o amigo considere "[...] lo que está por venir,/También lo que está por huir para siempre/De ti, de mi, / De las personas que nos escuchan", completando em seguida: "Me refiero a uma sombra". Tomás Lago deve perceber o escuro de si mesmo e de sua época; "perceber esse escuro não é uma forma de inércia ou de passividade, mas implica uma habilidade particular que [...] equivale a neutralizar as luzes que provêm da época para descobrir as suas trevas, o seu escuro especial, que não é, no entanto, separável daquelas luzes" 28 . Contudo, ao longo da segunda estrofe do poema, essa sombra será moldada lentamente, verso após verso, designando categorias abstratas e categorias concretas. A técnica utilizada cria um jogo retórico de apresentação e desenvolvimento no qual as categorias e suas descrições são dispostas de forma equilibrada e simétrica:

brosas; intercalar em um relato traços circunstanciais, exigidos agora pelo leitor”. BORGES, Jorge Luis. Elogio de la sombra, 1969, p. 9.

25 "O segundo crepúsculo./Esse outro hábito do tempo, a noite./A purificação e o esquecimento". Ibidem, p. 19.

26 "essa moeda que nunca é a mesma". Ibidem, p. 15.

27 "Talvez da minha sombra/surjam, fatais e ilusórios, os dias.” Ibidem, p. 19.

28 AGAMBEN, Giorgio. O que é o contemporâneo? e outros ensaios, 2009, p. 63. 
Me refiero a una sombra,

A ese trozo de ser que tú arrastras

Como a una bestia a quien hay que dar de comery de beber

$Y$ me refiero a un objeto,

A esos muebles de estilo que tú coleccionas con horror

A esas coronas mortuorias y a esas espantosas sillas de montar,

(Me refiero a una lus).

$[\ldots]$

O primeiro verso apresenta a imagem da sombra; os dois versos seguintes a desenvolvem: ela é o ser incompleto de Tomás Lago, que apesar de seu caráter fragmentário e animalesco deve ser alimentado e cuidado para que não adoeça nem morra. O terceiro verso apresenta a categoria "objeto", desdobrada nos dois próximos versos em itens concretos: móveis de antiquário, coroas fúnebres, selas de montaria. Esses objetos definem materialmente o ser de Tomás Lago, são suas marcas, aquilo que ele decide colecionar como artefatos de um museu pessoal. Cada item desta coleção é uma pequena luz idílica do passado cintilando na escuridão do presente, por isso Nicanor Parra sente-se obrigado a mencionar essa luz, embora ela só possa ser apreendida entre parênteses: "(Me refiero a una luz)". Trata-se de uma luz oblíqua e virtualmente inalcançável, no entanto, Tomás Lago deve observá-la, pois o que está em jogo, aqui, é a sobrevivência de uma imagem dialética e, portanto, a sua própria sobrevivência na história, a sua própria contemporaneidade. Trata-se "antes de tudo, de uma questão de coragem: porque significa ser capaz não apenas de manter o olhar fixo no escuro da época, mas também de perceber nesse escuro uma luz que, dirigida a nós, distancia-se infinitamente de nós. Ou ainda: ser pontual num compromisso ao qual se pode apenas faltar" ${ }^{29}$. Talvez por isso Luciana di Leone tenha me dito, numa conversa, que "as imagens dessa estrofe são insistentemente marcadas por uma ansiedade de referência, por uma repetição gaguejante da expressão 'Me refiero', que, no entanto, sempre falha".

Em "Palavras a Tomás Lago", Nicanor Parra se refere a uma sombra para referir-se também aos objetos que Tomás Lago coleciona com horror. Esse horror não tem outra natureza a não ser a representação dialética da história sobre a qual Walter Benjamin se debruçou ao longo de sua vida: a consciência do homem histórico e a desconfiança de que tudo pode desmoronar e se perder. Por que Tomás Lago colecionava móveis de antiquário, coroas fúnebres, selas de montaria? É impossível

29 Ibidem, p. 65. 
não pensar que esses objetos evocam imagens de morte e abandono. Contudo, é nesses objetos antiquados que podemos ver com maior precisão a marcha inquietante do tempo e os fragmentos do passado que emergem e permanecem no presente como fontes de energia política.

\begin{abstract}
O surrealismo orgulha-se de uma surpreendente descoberta: foi o primeiro a ter pressentido as energias revolucionárias que transparecem no "antiquado”, nas primeiras construções de ferro, nas primeiras fábricas, nas primeiras fotografias, nos objetos que começam a extinguir-se, nos pianos de cauda, nas roupas de mais de cinco anos, nos locais mundanos, quando a moda começou a abandoná-los. Esses autores compreenderam melhor do que ninguém a relação entre esses objetos e a revolução. Antes desses videntes e intérpretes de sinais, ninguém havia percebido de que modo a miséria, a miséria dos interiores, as coisas escravizadas e escravizantes transformavam-se em niilismo revolucionário ${ }^{30}$.
\end{abstract}

O niilismo revolucionário percebido pelos surrealistas nos objetos "antiquados" tem relação direta com a perda do valor de uso desses objetos. Colocá-los de volta em circulação por meio de suas palavras e manifestações era um modo (ainda que precário) de mantê-los em circulação, era perceber a escuridão do presente e, ao mesmo tempo, a luz oblíqua dos objetos passados. "Somente quem soubesse considerar o próprio passado como fruto da coação e da necessidade seria capaz de fazê-lo, em cada presente, valioso ao máximo para si mesmo"31. Esse raciocínio levou Walter Benjamin a comparar os escombros do passado a preciosos blocos sobre os quais o homem tem de esculpir o seu futuro ${ }^{32}$. Ao perceber a energia revolucionária dos objetos colecionados por Tomás Lago, Nicanor Parra é iluminado pelo niilismo estimulante que eles podem despertar; é também a esta luz que o poeta se refere, a esta iluminação profana que nos remete a uma consciência histórica, bem como à percepção de que nossas vidas são inseparáveis de suas formas e de que a forma dos objetos que nos cercam, quaisquer que sejam, não devem ser tomadas como formas separadas de nossas vidas. " $A$ veces las situaciones se iluminan desde dentro y no desde fuera", diz Nicanor Parra. "Me aparto de la fotografía y hurgo lo permanente y transitorio, el momento, lo cambiable en el plano sensorial y mental... Se me podrá encontrar contactos con los surrealistas o con el realismo mágico de otros..."33.

30 BENJAMIN, Walter. Obras escolbidas, vol. 1, 1987, p. 25.

31 Ibidem, p. 41.

32 Ibidem, p. 41-42.

33 "Às vezes as situações se iluminam desde dentro e não desde fora. Afasto-me da fotografia e mergulho no permanente e transitório, no momento, no mutável no plano sensorial e mental... Poderão encontrar contatos meus com os surrealistas ou com o realismo mágico de outros”. ALFARO, Luis Droguett. "Diálogo apócrifo con Nicanor Parra", Atenea, 1959, n.p. 
É Desse modo que, a partir da terceira estrofe de "Palavras a Tomás Lago", Nicanor

Parra realiza "um salto de tigre em direção ao passado" 34.

$[\cdots]$

Te vi por primera vez en Chillán

En una sala llena de sillas y mesas

A unos pasos de la tumba de tu padre.

Tú comías un pollo frío,

A grandes sorbos hacías sonar una botella de vino.

Dime de dónde habías llegado.

El nocturno siguió viaje al sur,

Tú hacías un viaje de placer

$\mathrm{O}$ ¿te presentabas acaso vestido de incógnito?

En aquella época ya eras un hombre de edad, Luego vinieron unas quintas de recreo

Que más parecían mataderos de seres humanos:

Había que andar casi toda la noche en tranvía

Para llegar a ese lugar maldito,

A esa letrina cubierta de flores.

Vinieron también esas conferencias desorganizadas, Ese polvo mortal de la Feria del Libro,

Vinieron, Tomás, esas elecciones angustiosas,

Esas ilusiones y esas alucinaciones.

¿Qué triste ha sido todo esto!

¿Qué triste! pero iqué alegre a la vez!

¿Qué edificante espectáculo hemos dado nosotros

Con nuestras llagas, con nuestros dolores!

A todo lo cual vino a sumarse un afán,

Un temor,

Vinieron a sumarse miles de pequeños dolores,

¡Vino a sumarse, en fin, un dolor más profundo y más agudo!

Piensa, pues, un momento en estas cosas,

En lo poco y nada que va quedando de nosotros,

Si te parece, piensa en el más allá,

Porque es justo pensar

Y porque es útil creer que pensamos.

34 BENJAMIN, Walter. Obras escolbidas, vol. 1, 1987, p. 230. 


\section{Referências bibliográficas}

ABRAMS, Meyer H. The mirror and the lamp: romantic theory and the critical tradition. Londres/Oxford/Nova York: Oxford Press University, 1971.

AGAMBEN, Giorgio. Ideia da prosa. Lisboa: Cotovia, 1999.

AGAMBEN, Giorgio. O que é o contemporâneo? e outro ensaios. Chapecó: Argos, 2009.

ALFARO, Luis Droguett. "Diálogo apócrifo con Nicanor Parra”, Atenea, n. 383, n.p.

BENJAMIN, Walter. Magia e técnica, arte e política, ensaios sobre literatura e bistória da cultura. Obras escolbidas, vol. 1. São Paulo: Brasiliense, 1987.

BENJAMIN, Walter. A modernidade e os modernos. Rio de Janeiro: Tempo Brasileiro, 2000.

BORGES, Jorge Luis. Elogio de la sombra. Barcelona/Buenos Aires: Emecé, 1969.

BORGES, Jorge Luis. Siete noches (Conferencias pronunciadas por Borges en 1977). Buenos Aires: Fondo de Cultura Económica, Ediciones Nuevo País, 1980.

BORGES, Jorge Luis. Obras completas (1923-1972). Buenos Aires: Emecé, 1984.

DE COSTA, René. "Para una poética de la (anti)poesía". In: PARRA, Nicanor. Poemas y antipoemas. Madrid: Cátedra, 2017. p. 9-40.

DI LEONE, Luciana. Poesia e escolhas afetivas. Rio de Janeiro: Rocco, 2014.

GAGNEBIN, Jeanne-Marie. "Prefácio - Walter Benjamin ou a história aberta". In: BENJAMIN, Walter. Magia e técnica, arte e politica, ensaios sobre literatura e bistória da cultura. Obras escolbidas, vol. 1. São Paulo: Brasiliense, 1987, p. 7-19.

GAGNEBIN, Jeanne-Marie. Obra gruesa. Santiago de Chile: Editorial Universitaria, 1969.

GAGNEBIN, Jeanne-Marie. Poemas y antipoemas. Madrid: Cátedra, 2017.

PLATÃO. A república. Lisboa: Calouste Gulbenkian, 2014.

WERNER, Christian. "Introdução”. In: HOMERO. Odisseia. São Paulo: Cosac Naify, 2014. 
Submissão: $15 / 05 / 2020$

Aceite: $20 / 09 / 2020$

https://doi.org/10.5007/2176-8552.2020.e73612

Esta obra foi licenciada com uma Licença Creative Commons Atribuição-NãoComercial 4.0

Universidade Federal de Santa Catarina - 1oSemestre de 2020 